\title{
TIME BUFFERS IN CONSTRUCTION PROCESS SCHEDULING
}

\author{
Magdalena Rogalska ${ }^{1}$, Zdzisław Hejducki ${ }^{2}$ \\ ${ }^{1}$ Faculty of Civil and Sanitary Engineering, Lublin University of Technology, \\ ul. Nadbystrzycka 40, 20-618 Lublin, Poland.E-mail: m.rogalska@pollub.pl \\ ${ }^{2}$ Institute of Building Engineering, Wrocław University of Technology, \\ Wybrzeże Wyspiańskiego 27, 50-370 Wrocław, Poland.E-mail: zdzislaw.hejducki@pwr.wroc.pl \\ Received 3 Jan 2006; accepted 27 Sept 2006
}

\begin{abstract}
Potential applications of the CCS/BM method in the scheduling of continuous LSM (Linear Scheduling Model) construction activities are considered. The effect of time buffers - feeding buffers (FB) and project buffers (PB) - on total project realisation time (TT) is examined. Feeding buffers are found to have no direct full influence on TT if construction activities continuity is assumed. The influence of FBs on TT for other conditions considered in this paper still needs to be examined.
\end{abstract}

Keywords: critical chain, time buffers, Linear Scheduling Model.

\section{Introduction}

This paper deals with construction work scheduling. Current publications on this subject propose such scheduling methods as: LSM (Linear Scheduling Model), LOB (Line of Balance) and CPM/PERT network planning for several objective functions: the least cost, limited resources, work priorities etc in both a deterministic approach and probabilistic one. The scheduling of linear continuous construction process operations has been the subject of numerous papers: Arditi et al (2001a, 2001b), Hegazy et al (1993), Johnston (1984), in which graphical planning techniques are described. Also the synchronisation of construction activities conducted in sectors (parts of a building structure) has been investigated: LOBs allow one to link different continuous activities conducted simultaneously in many sectors. In other papers: Hamerlink (1995), Hamerlink and Rowings (1998), Rabhar and Rowings (1992), Harris and Ioannou (1998) new graphical planning techniques are proposed. Solutions to many specific problems: Chrzanowski and Johnson (1986) and Zavadskas (2000) (selection of the optimum organisational design) are offered.

The present paper deals with the planning of tasks when time buffers are included and the continuity of construction process operations is maintained. Minimum time is adopted as the criterion for selecting an organisational design (Zavadskas et al, 1997). Moreover, methods of sequencing tasks in sectors by means of time couplings, Afanasjev and Afanasjev (2000), Hejducki (2000), Mrozowicz (1997), are presented. In other words, the considered problem represents an expansion of LSM with the sequencing problem.

Among many factors affecting the size of a project buffer there are the following risk factors: disturbances in the supply of materials and equipment, irregular financ- ing, design errors, inclement weather, equipment failures, inefficient contractors, administrative-legal disturbances etc. In the literature on the CCS/BM methodology (critical chains) it is suggested that additional reserves (buffers) should be introduced: a project buffer (PB) at the end of the project controlling path and a feeding buffer (FB) beyond the latter. These are reserves for, among other things, deliveries of materials and machines and the work of contractors.

When negotiating dates for completing tasks, contractors try to make sure that they will be able to meet the contractual deadlines. They do it intuitively by introducing time reserves (buffers), taking both their subcontractors and suppliers into account. The proposed arbitrary reduction of task execution time (eg by $50 \%$; Goldratt, 1990, 1992, 1994, 1997; Goldratt and Fox, 1986) for particular participants in the project seems to be very subjective and requires practical verification. Hence many researchers attempt to reduce random problems to deterministic ones which then can be easily applied in practice. There are many conceptual and model solutions for single problems. In case of more complex projects, the scheduling problem becomes difficult and computationally complex. This is particularly true of the sequencing problem, when technological and organisational constraints and objective functions (for, let's say, $T \rightarrow \min$ ) are taken into account.

When examining the course of construction projects, one can notice that the contractors' approach to activity duration estimation conflicts with that of the project developer (the general contractor in $\mathrm{PM} / \mathrm{CM}$ ). A contractor usually wants to ensure the continuity of performance of his task in order to minimise the costs associated with work stoppages (and the resulting lower productivity) and with making materials and equipment secure. 
The developer (the general contractor in $\mathrm{PM} / \mathrm{CM}$ ) usually does his/her best to control the construction process in such a way that as soon as an opportunity arises the next process operation can start. Because of different size and execution time of the tasks involved (earth work, foundation work, construction work, finishing work etc), the assurance of their continuity may result in stoppages for the companies carrying them out as they wait for the completion of the works.

Computations performed for a set of works show that the assurance of continuity of the tasks to be carried by contractors results in a longer total project time than if the contractors worked with stoppages but the proper sequence of the tasks was ensured. Furthermore, changes in the sequence in which works are carried out in many sectors contribute to an increase/decrease in the fixed project time.

\section{Matrix modelling (MM) of a set of construction activities}

Matrix notation makes it easier to enter data when schedules are drawn up by computers. Then the construction process can be divided, eg Work Breakdown Structures (WBS), according to the construction technology into types of work, and the tasks involved in the construction of building structure components can be specified. A matrix model allows one to determine a technological sequence by determining the matrix code and to distinguish units such as single dwelling houses, building structure parts separated by, for instance, expansion joints, building storeys in which finishing work can be carried out in parallel, flow-wise or sequentially etc. A matrix (a sequence of digits), incorporating expert engineering knowledge, can be used in various standard computer software systems, such as Mathematica or Matlab, or stand-alone programmes such as Organisator. Matrix models of construction projects can be used to compute schedule parameters.

\section{Basic assumptions for computations}

A schedule key factors, such as work start and completion dates, the size of sectors, the number of contractors, the sequence of sectors, the controlling path and the total project time, must be computed for given constraints. Stoppages in the work of contractors and situations when work in a given sector is not done in a continuous way are allowed (this obviously affects the total project time, TT). Computer programmes - the successive versions of the original POTOKI software - are used for computations. The software has been updated as improvements in the method (incorporation of new constraints) and advances in computer technology have been made. The latest version is ORGANIZATOR. It is to be updated soon to include weather-related disturbances in road building and TOC (Goldratt's theory of constraints) through the introduction of feeding buffers, a project buffer and the reduction of the time of executing construction process operations. ORGANIZATOR does not generate Gantt's charts but cyclograms and networks of dependencies (the arrangement of activities in sectors and the relations between the activities). The key elements in the cyclograms are the times of carrying out particular activities in sectors and controlling points (CP). The following symbols are used:

LT (least time) - the shortest time between an activity in progress and the next activity,

LD (least distance) - the shortest distance between an activity in progress and the next activity,

$\mathrm{CPH}$ (controlling path) - the critical path of activities [days],

CL (controlling link) - a graphical link between successive activities (on the controlling path),

CP (controlling point) - a critical point corresponding to the commencement of the next activity,

$\mathrm{T}$ the duration of an activity,

TT (time total) - the total time of carrying out a project,

$\mathrm{m}$ the number of activities,

$\mathrm{n}$ the number of sectors.

Taking into account risk factors as feeding time buffers (FB) and project buffers (PB), their effect on the total project time was examined. The Organizator program, which is based on combinatorial permutational optimisation algorithms, was used for this purpose. The project realisation time

$$
T \rightarrow T_{\min }
$$

was adopted as the objective function. The following were assumed for computing schedule parameters:

1) the continuity of construction process operations in a technological sequence in sectors (time couplings method TCM I)

\section{LT1,1...LTn, $\mathrm{m}=0$;}

2) the continuity of construction process operations in a technological sequence in sectors (time couplings method TCM II)

$\mathrm{LD} 1,1 \ldots . \mathrm{LDn}, \mathrm{m}=0$.

3) a minimum controlling path requirement (time couplings methods TCM III, IV and V)

$\mathrm{CPH}=\mathrm{TTmin}$.

Condition I (time couplings method TCM I) applies to cases when the priority is to ensure the continuity of activities $\mathrm{P} 1$.....Pm in sectors $\mathrm{S} 1$....Sn. This is usually the assurance of work continuity for contractors or equipment. Because of the technology used (eg seamless concreting), work continuity assurance may become a priority. The same applies to a leading activity, ie one which enables the start of all works contingent on it. It often happens that if stoppages are taken into account, hiring a particular contractor or equipment becomes unprofitable. Also repeated undertaking of work by the same contractor may be unprofitable because of the costs of equipment transport and assembly. Some highly specialised contractors undertake a 
task on condition that the continuity of their work will be assured. In some services, the demand exceeds supply and work continuity assurance for some contractors becomes a priority. The data generated by the ORGANIZATOR program are specified in Fig 1.

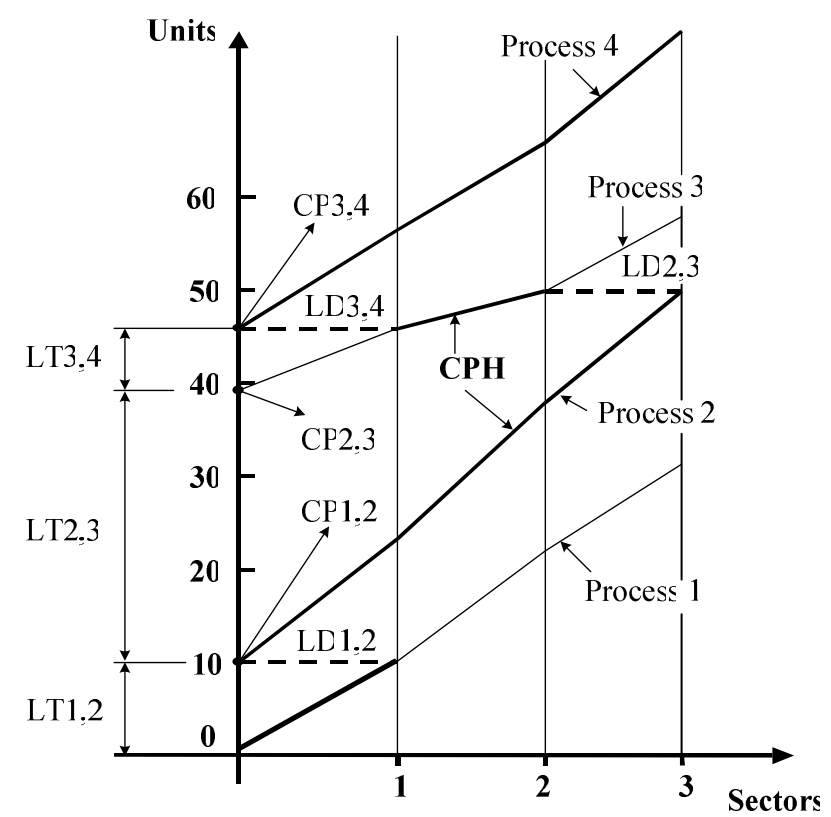

Fig 1. Symbols used to describe continuous processes (Process $1, \ldots$ Sectors)

Predefined and deterministically calculated sectors $\mathrm{S} 1, \mathrm{~S} 2 \ldots . \mathrm{S}_{\mathrm{n}-1}, \mathrm{Sn}$ and activities $\mathrm{P} 1, \mathrm{P} 2 \ldots . \mathrm{P}_{\mathrm{m}-1}, \mathrm{Pm}$ in a technological sequence and their performance times $\mathrm{T} 1,1 \ldots \mathrm{Tn}, \mathrm{m}$ are used as the input. At this stage, no final sequence of activities in the particular sectors is fixed (it will be ultimately fixed after basic computations during the first optimisation). A certain sequence of sectors is assumed but it can be easily changed at a later stage by selecting the 'optimise' option in the program (the whole operation takes a few seconds and it is not necessary to re-enter the data or to analyse them in detail). The computations usually yield the best results when the duration of the activities in the final sector is the shortest in comparison with that of other activities. As a result of the computations, one obtains the total time (TT) in which the project will be completed. The time is longer then or equal to the minimum project duration TT min (in minutes) determined by other 5 methods implemented in the ORGANIZATOR program. Time intervals LT1,1... LTn, $m$ between the activities in progress and the next ones are always equal to zero, ie the continuity of activities P1....Pm is ensured. Probably no continuity of work in the sectors will be assured (sometimes it will be assured but this is not a priority). The priority dependences, ie the ones for which LTs must be always equal to zero, used as the basis for drawing up a schedule are shown in Figs 2, 3 .

\section{Analysis of time buffers in Linear Scheduling Model (LSM)}

Selected cyclograms generated for exemplary numerical data are shown below. The aim of the analysis was to determine the effect of feeding buffers (FB) in the total project time (TT). The analysis was performed for two locations of the controlling path in the cyclogram: 1) with extreme initial activities taken into account and 2) with extreme final processes. This entails a change in the location of FBs and in the course of the controlling path in the new $\mathrm{CC}$. The durations of the activities are given in the tables below: the input data in Table 1 and the modified (using the Goldratt's method) data in Tables 2, 3. For the sake of clarity, networks of dependences between the activities, the classical controlling path and the critical chains with time buffers FB and PB are illustrated below.

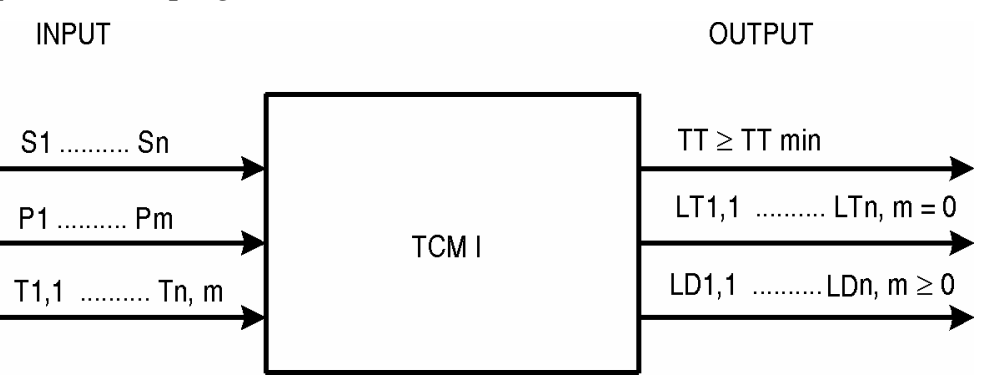

Fig 2. Computational scheme for condition I

INPUT

OUTPUT

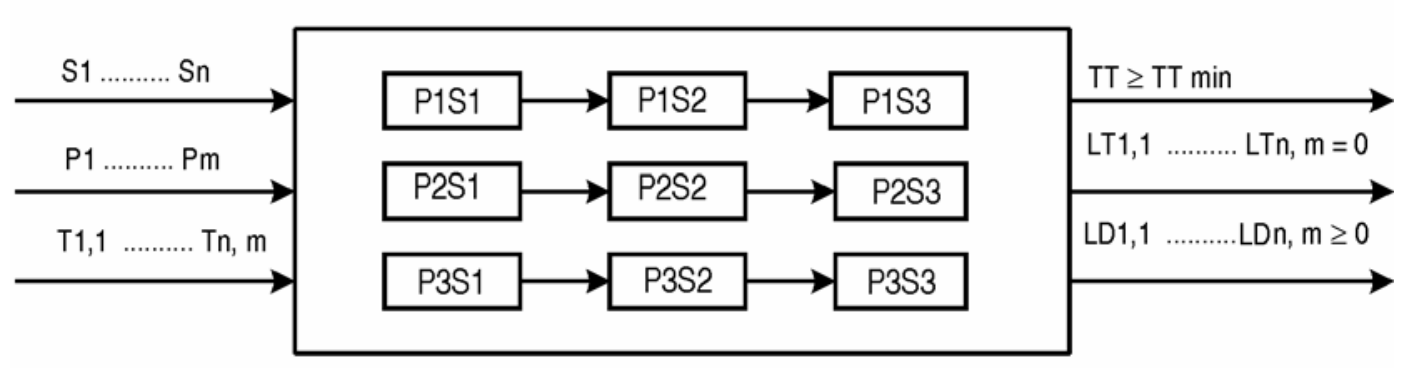

Fig 3. Priority dependences 
Table 1. Input data

\begin{tabular}{c|c|c|c|c}
\hline Sector & Process 1 & Process 2 & Process 3 & Process 4 \\
\hline 1 & 4 & 8 & 8 & 12 \\
\hline 2 & 8 & 12 & 8 & 16 \\
\hline 3 & 12 & 8 & 12 & 8 \\
\hline 4 & 16 & 12 & 8 & 8 \\
\hline
\end{tabular}

Table 2. Numerical data modified in accordance with Goldratt's method

\begin{tabular}{c|c|c|c|c|c|c|c|c|c}
\hline Sector & P1 & FB1 & P2 & FB2 & P3 & FB3 & P4 & FB4 & PB \\
\hline 1 & 2 & 0 & 4 & 0 & 4 & 0 & 6 & 0 & 0 \\
\hline 2 & 4 & 0 & 6 & 0 & 4 & 0 & 8 & 7 & 0 \\
\hline 3 & 6 & 0 & 4 & 7 & 6 & 7 & 4 & 0 & 0 \\
\hline 4 & 8 & 0 & 6 & 0 & 4 & 0 & 4 & 0 & 19 \\
\hline
\end{tabular}

Table 3. Numerical data modified according to Goldratt's method - FB values for controlling path

\begin{tabular}{c|c|c|c|c|c|c|c|c|c}
\hline Sector & P1 & FB1 & P2 & FB2 & P3 & FB3 & P4 & FB4 & PB \\
\hline 1 & 2 & 0 & 4 & 0 & 4 & 2 & 6 & 0 & 0 \\
\hline 2 & 4 & 0 & 6 & 0 & 4 & 0 & 8 & 0 & 0 \\
\hline 3 & 6 & 0 & 4 & 0 & 6 & 0 & 4 & 0 & 0 \\
\hline 4 & 8 & 7 & 6 & 5 & 4 & 7 & 4 & 0 & 19 \\
\hline
\end{tabular}

The computations performed using the ORGANIZATOR program yielded durations of the particular activities in the sectors, which were then used to construct a cyclogram by the LSM method. Two controlling paths linking the initial and final activities have appeared in Figs 4, 5. Owing to the assurance of the continuity of the activities (TCM I), LT 1, LT 2 and LT 3 now make for the maximum proximity of activities 1,2 and 3. When examining the course of the activities and tracing the controlling path $(\mathrm{CPH})$, one can notice that the minimum project time is obtained by adding up the appropriate durations of the activities in the sectors, which may form two independent controlling paths. The cyclograms and the controlling paths are shown in Figs 4, 5.

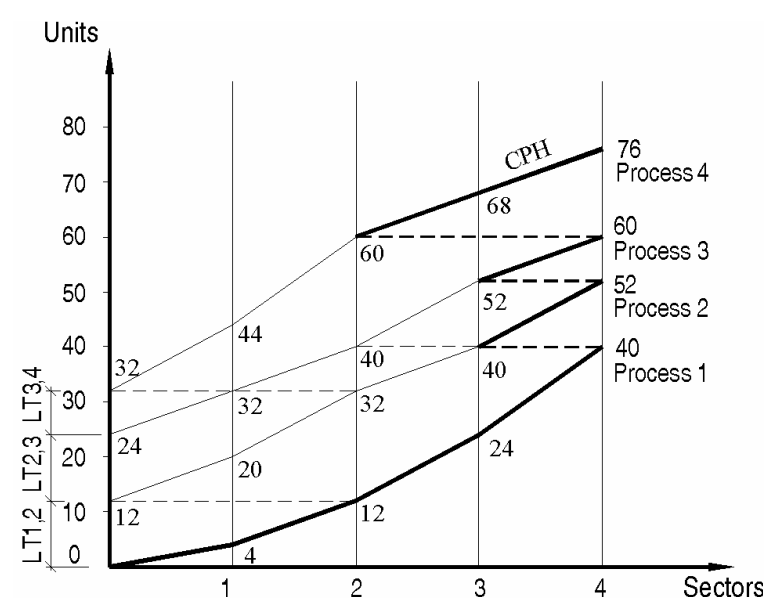

Fig 4. Cyclogram with controlling path (course 1) (Units, Process $4, \ldots$, Sectors)

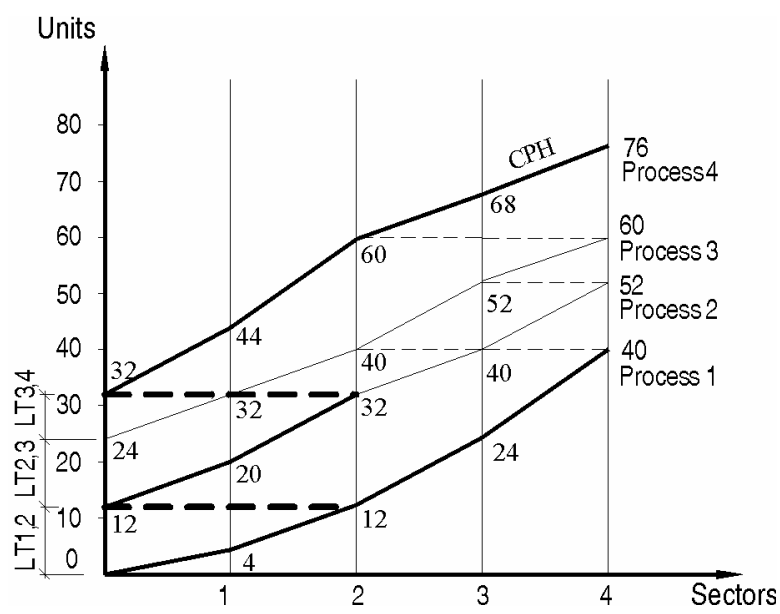

Fig 5. Cyclogram with critical path (course 2) (Units, Process $4, \ldots$, Sectors)

Two courses of the controlling path for the networks of interdependences are shown in Figs 6, 7. When examining the layout of the activities, one can notice that because of the imposed constraints (condition I, TCM I) all the activities performed in the sectors have a critical character even though they are not on the controlling path. Because of the activities performance continuity condition (TCM I) the extension of the duration of any of activities will affect the total project time TT.

The modified (using Goldratt's method) activity duration times are shown in Table 2. Network of dependences with time buffers is shown in Fig 8. FB and PB values for the sequence of activities and for the controlling path were introduced. Computations were performed using the ORGANIZATOR program and the results are in Fig 9. When examining the cyclogram, one can notice that the feeding buffers became part of the critical chain, directly affecting total project time TT. Even though the particular activity durations were reduced by half and the reduced durations were replaced by a buffer of $25 \%$, $\mathrm{TT}=74$ units was obtained, ie the total project time was not proportional but only slightly reduced - from 76 to 74 units.

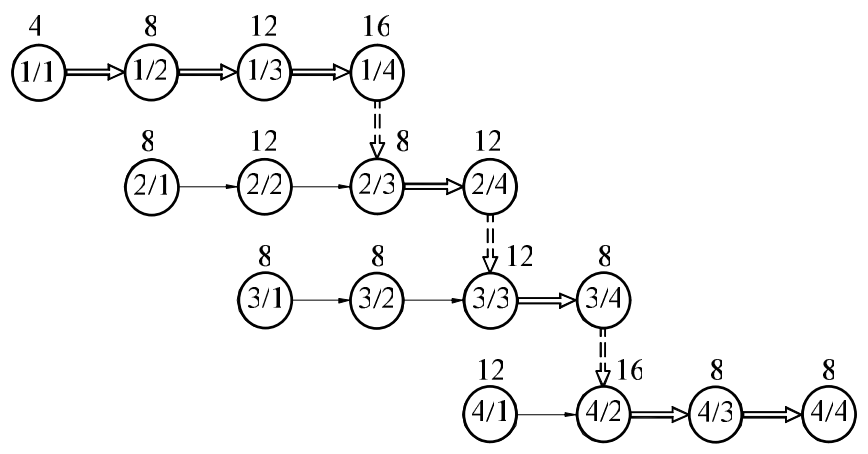

Fig 6. Network of dependences for input data given in Table $1, \mathrm{CPH}$ as bold arrows 


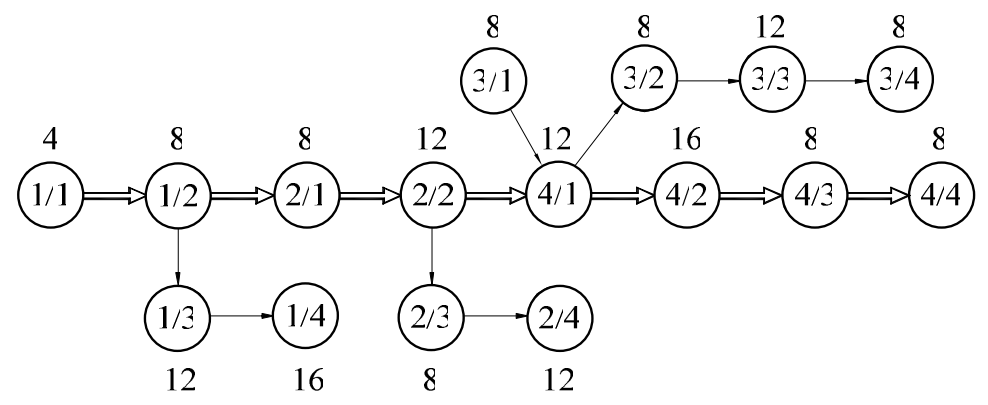

Fig 7. Network of dependences for input data in Table 1

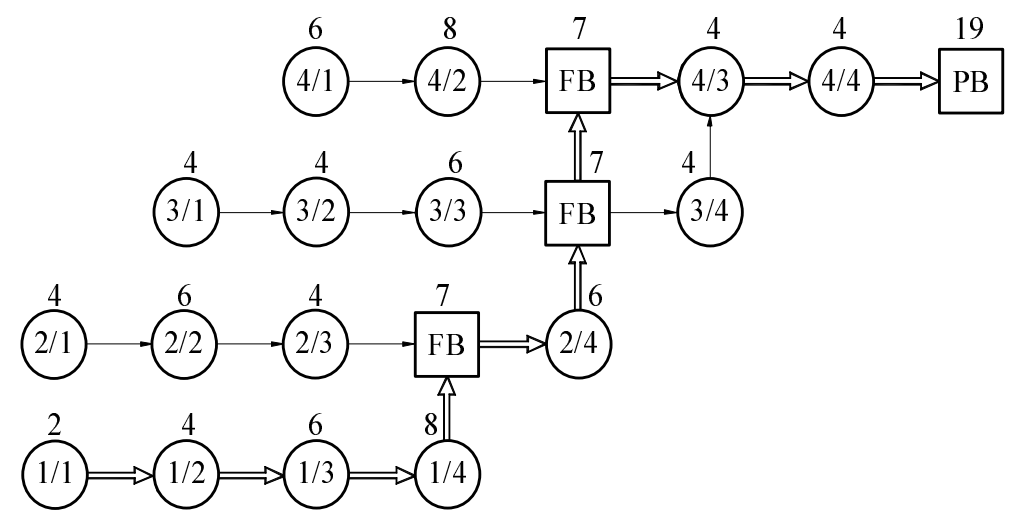

Fig 8. Network of dependences with time buffers

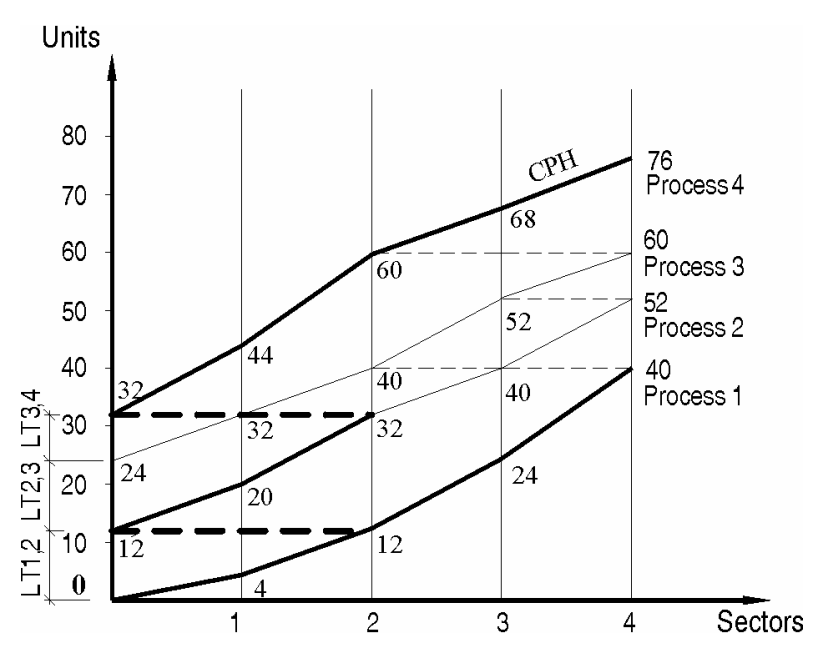

Fig 9. Cyclogram with critical chain and time buffers (Units, Process 4, ..., Sectors)

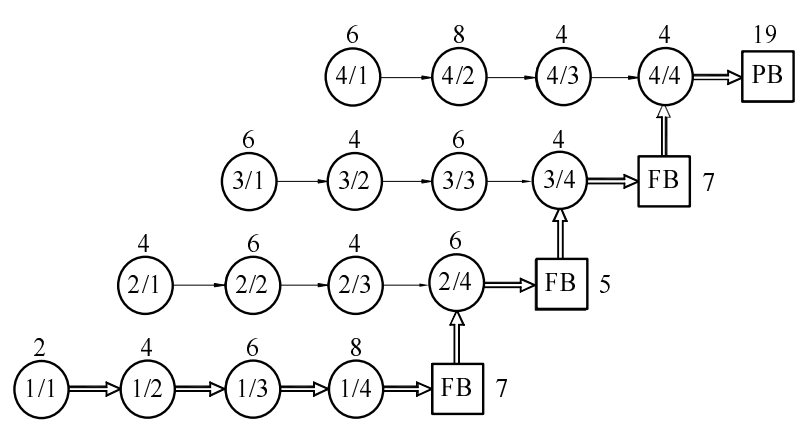

Fig 10. Network of dependences incorporating time buffers

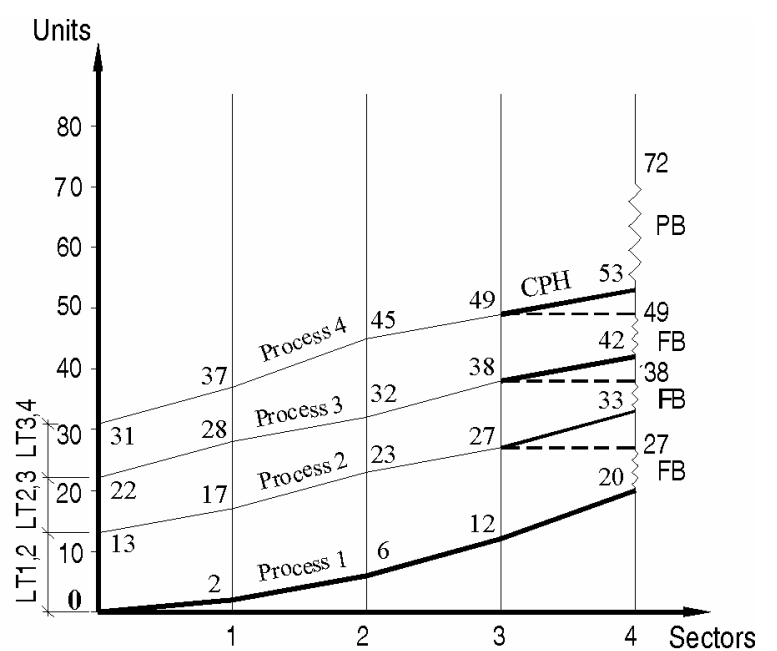

Fig 11. Cyclogram with critical chain and time buffers (Units, Process $4, \ldots$ )

Table 3 with the entered modified (according to Goldratt's method) numerical data (durations of activities in sectors) was compiled on the basis of the variant with the controlling path (formed of final activities) shown in Fig 5. The network of dependences incorporating time buffers is shown in Fig 10. The numerical values of FBs were located at the ends of the sequences of activities. An analysis of the cyclogram (ensured activities continuity (TCM I), computations performed using the ORGANIZATOR program) in Fig 11 shows that the feeding buffers are now located in the critical chain of activities and on the controlling path and so have a direct bearing on the total project time $-\mathrm{TT}=72$ units. The feeding buffers $(\mathrm{FB})$ have a 
character of activities and they are treated as activities in computations. A reduction in their size contributes to a reduction in the total project time.

\section{Conclusion}

The above analysis and computations have shown that the reduction of the duration of individual activities, taking into account $25 \%$ time buffers, does not result in a proportionally shorter total project time. Goldratt's method is an oversimplification and it may suit only sequential activities. The total project time depends on what critical chain components are selected. If one examines the graphical models (cyclograms constructed in accordance with the LSM methodology), it becomes apparent that if a critical chain located as closely as possible to the cyclogram's right edge is adopted, this results in a shorter total project time. Feeding buffers (FB) in cyclograms must be treated as separate activities in order to ensure the continuity of work for contractors and avoid financial losses due to unnecessary stoppages. Using the task scheduling algorithms included in the ORGANIZATOR computer program one can reduce the total project time by changing the sequence in which activities are performed in sectors, provided the work sectors are independent and available. Depending on the quantified unit risk of a given activity it is possible to adopt FBs and PBs of different size. Through them one can take into account the particular technical conditions of different construction processes, the local constraints and the risk factors.

\section{References}

AFANASJEV, V. A; AFANASJEV, A. V. (2000) Organization of construction work. Sankt-Petersburg. 152 p. (in Russian).

ARDITI, D.; TOKDEMIR, O. B.; SUH, K. (2001) Scheduling system for repetitive unit construction using line-ofbalance technology. Engineering Construction and Architectural Management, 8(2), p. 90-103.

ARDITI, D.; TOKDEMIR, O. B.; SUH, K. (2001) Effect of learning on line-of-balance scheduling. International Journal of Project Management, 19(5), p. 265-277.

CHRZANOWSKI, E. N.; JOHNSTON, D. W. (1986) Application of linear construction. Journal of Construction Engineering and Management, 112(4), p. 476-491.
GOLDRATT, E. M. (1997) Critical chain. Great Barrington: The North River Press. 246 p.

GOLDRATT, E. M.; FOX, R. E. (1986) The race. New York: North River Press. 179 p.

GOLDRATT, E. M. (1990) The haystack syndrome: sifting information out of the data ocean. New York: North River Press. 262 p.

GOLDRATT, E. M. (1994) It is no luck. Great Barrington: North River Press. 283 p.

GOLDRATT, E. M. (1992) The goal. 2nd revised edition. Great Barrington: North River Press. 337 p.

HAMERLINK, D. J. (1995) Linear scheduling model: The development of a linear scheduling model with micro computer application for highway construction control. $\mathrm{PhD}$ thesis, Iowa State University, USA.

HAMERLINK, D. J.; ROWINGS, J. E. (1998) Linear scheduling model: development of controlling activity path. Journal of Construction Engineering and Management, 124(4), p. 266-268.

HARRIS, R. B., IONNOU, P. G. (1998) Scheduling projects with repeating activities. Journal of Construction Engineering and Management, 124(4), p. 269-278.

HEGAZY, T.; MOSELHI, O.; FAZIO, P. (1993) BAL: an algorithm for scheduling and control of linear projects. In Proc of the AACE Transactions, May 1993, Dearborn, Michigan, p. C.8.1-C.8.14.

HEJDUCKI, Z. (2000) Time couplings in methods of organizing complex construction process operations. Wrocław: Publishing House of Wrocław University of Technology (in Polish).

JOHNSTON, D. W. (1984) Linear scheduling method for highway construction. Journal of Construction Division, 107(2), p. 247-261.

MROZOWICZ, J. (1997) Methods of organizing construction activities taking into account time couplings. Wrocław: Publishing House of Wrocław University of Technology (in Polish).

RABHAR, F. F.; ROWINGS, J. E. (1992) Respective activity scheduling process. Transactions of the American Association of Cost Engineers, Vol 2, p. 0.5.1-0.5.8.

ZAVADSKAS, E. K. (2000) Mehrkriterielle Entscheidungen im Bauwesen. Vilnius: Technika. $207 \mathrm{~S}$.

ZAVADSKAS, E. K.; KAKLAUSKAS, A.; TURSKIS, Z. (1997) Multicriteria decision-making system for building refurbishment. Statyba (Civil Engineering), 4(12), p. 62-67.

\section{LAIKO ATSARGOS STATYBOS PROCESU KALENDORINIAME PLANAVIME}

\section{Rogalska, Z. Hejducki}

Santrauka

Straipsnyje nagrinejjamos CCS/BM metodo pritaikymo galimybės nepertraukiamo LSM (grafinio linijinio modelio) statybos procesų kalendoriniam planavimui. Tikrinama laiko atsargų, tokių kaip laiko atsargos pasirengti (FB) ir laiko atsargos projektui baigti (PB), itaka projekto trukmei (TT). Nustatyta, kad laiko atsargos pasirengti neturi tiesioginès itakos projekto trukmei, jeigu daroma prielaida, kad statybos procesai yra nepertraukiami. Esant kitoms straipsnyje aptariamoms salygoms, pasirengimo laiko atsargu (FB) poveikį bendrajai projekto trukmei (TT) reikètų patikrinti.

Reikšminiai žodžiai: kritinè procesų seka, laiko atsargos, grafinis linijinis modelis.

Magdalena ROGALSKA. Assistant Professor at the Institute of Building of Technical University of Lublin (Poland) and the project manager in Construction Expertise Bureau KAMARO. Her research interests include civil engineering and management, special scheduling methods and risk. She was visiting with lectures the University of Brighton and Technical University in Prague.

Zdzisław HEJDUCKI. Assistant Professor at the Institute of Building Engineering of the University of Technology Wrocław, Poland. Research interests: civil engineering and management, special scheduling methods. 